\title{
Modelling the seasonal variability of the Antarctic Slope Current
}

\author{
P. Mathiot ${ }^{1}$, H. Goosse ${ }^{1}$, T. Fichefet ${ }^{1}$, B. Barnier ${ }^{2}$, and H. Gallée ${ }^{3}$ \\ ${ }^{1}$ Georges Lemaître Center for Earth and Climate Research, Earth and Life Institute, Louvain-la-Neuve, Belgium \\ ${ }^{2}$ CNRS/UJF Grenoble 1, Laboratoire des Ecoulements Géophysiques et Industriels (LEGI), Grenoble, France \\ ${ }^{3} \mathrm{CNRS} / \mathrm{UJF}$ Grenoble 1, Laboratoire de Glaciologie et Géophysique de l'Environnement (LGGE), Grenoble, France
}

Received: 22 December 2010 - Published in Ocean Sci. Discuss.: 11 January 2011

Revised: 9 June 2011 - Accepted: 10 June 2011 - Published: 6 July 2011

\begin{abstract}
One of the main features of the oceanic circulation along Antarctica is the Antarctic Slope Current (ASC). This circumpolar current flows westwards and contributes to communication between the three major oceanic basins around Antarctica. The ASC is not very well known due to remote location and the presence of sea ice during several months, allowing in situ studies only during summertime. Moreover, only few modelling studies of this current have been carried out. Here, we investigate the sensitivity of this simulated current to four different resolutions in a coupled ocean-sea ice model and to two different atmospheric forcing sets. Two series of simulations are conducted. For the first series, global model configurations are run at coarse $\left(2^{\circ}\right)$ to eddy-permitting $\left(0.25^{\circ}\right)$ resolutions with the same atmospheric forcing. For the second series, simulations with two different atmospheric forcings are performed using a regional circumpolar configuration (south of $30^{\circ} \mathrm{S}$ ) at $0.5^{\circ}$ resolution. The first atmospheric forcing is based on a global atmospheric reanalysis and satellite data, while the second is based on a downscaling of the global atmospheric reanalysis by a regional atmospheric model calibrated to Antarctic meteorological conditions.

Sensitivity experiments to resolution indicate that a minimum model resolution of $0.5^{\circ}$ is needed to capture the dynamics of the ASC in terms of water mass transport and recirculation. Sensitivity experiments to atmospheric forcing fields shows that the wind speed along the Antarctic coast strongly controls the water mass transport and the seasonal cycle of the ASC. An increase in annual mean of easterlies by about $30 \%$ leads to an increase in the mean ASC transport by about $40 \%$. Similar effects are obtained on the seasonal cycle: using a wind forcing field with a larger seasonal cycle $(+30 \%)$ increases by more than $30 \%$ the amplitude of
\end{abstract}

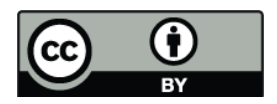

Correspondence to: P. Mathiot (pierre.mathiot@uclouvain.be) the seasonal cycle of the ASC. To confirm the importance of wind seasonal cycle, a simulation without wind speed seasonal cycle is carried out. This simulation shows a decrease by more than $50 \%$ of the amplitude of the ASC transport seasonal cycle without changing the mean value of ASC transport.

\section{Introduction}

The Antarctic Coastal Current (ACoC) or East Wind Drift (Deacon, 1937) is the southernmost current in the World Ocean. It flows parallel to the Antarctic coastline and is mainly westwards. Heywood et al. (2004) suggest that the $\mathrm{ACoC}$ might be circumpolar and not be disrupted, but the Antarctic Peninsula strongly impedes its flow. In parallel to the ACoC, the Antarctic Slope Front (ASF), described by Whitworth et al. (1998), affects the exchanges of heat, salt and freshwater across the continental shelf and the transport of water masses around the continent. It is associated with a westward surface intensified flow, which we refer to here as the Antarctic Slope Current (ASC). The ASF extends continuously from $120^{\circ} \mathrm{W}$ near the Amundsen Sea westwards to $55^{\circ} \mathrm{W}$ at the tip of the Antarctic Peninsula (Whitworth et al., 1998). This front is mainly attributed to coastal downwelling caused by the prevailing easterly winds there (Sverdrup, 1953). Heywood et al. (2004) note that the ASC and the associated current are distinct from the $\mathrm{ACoC}$ (found further south over the continental shelf), although in regions where the continental shelf is narrow, the $\mathrm{ACoC}$ and the topographically controlled ASC are sometimes difficult to differentiate (Heywood et al., 1998). For purposes of this paper, all westward flowing currents (ACoC, ASC, and southern branches of polar gyres) are grouped under the name Antarctic Slope Current (ASC), which can then be taken to represent total westward transport along the Antarctic continental margin.

Published by Copernicus Publications on behalf of the European Geosciences Union. 
Today, the total westward transport along the Antarctic coast is still debated. For example, across the Princess Elisabeth Trough (PET, Fig. 1), Heywood et al. (1999) estimate that the vertically integrated westward transport amounts to $45 \mathrm{~Sv}\left(1 \mathrm{~Sv}=10^{6} \mathrm{~m}^{3} \mathrm{~s}^{-1}\right)$, while Bindoff et al. (2000) and Meijer et al. (2010) suggest values of $16 \mathrm{~Sv}$ and $28 \mathrm{~Sv}$, respectively. Strong discrepancies are also found along the Antarctic coast of the Australian Antarctic Basin. McCartney and Donohue (2007) estimate the total westward transport to be $76 \mathrm{~Sv}$. This is stronger than the $29 \mathrm{~Sv}$ proposed by Bindoff et al. (2000). The seasonal cycle of the total westward transport is also not well known. The recent observational study conducted by Nunez-Riboni and Fahrbach (2009) along Fimbul Ice Shelf at $0^{\circ} \mathrm{E}$ suggests that the seasonal cycle of the current velocity is mainly due to the easterly winds. A maximum current velocity is found during May and June when the easterlies are stronger. In modeling studies, Aoki et al. (2010) and Mathiot et al. (2010) obtained a similar seasonal cycle of the ASC transport.

A better knowledge of the variability of the ASC and of its driving mechanisms, as well as the quantification of the contribution of the driving mechanisms to the variability of this current, would lead to a better understanding of its effects on the biology and physics of the Southern Ocean (e.g. Smedsrud et al., 2006; Rintoul, 2007; Pauly et al., 2000; Heywood et al., 2004). Unfortunately, shipboard field work in this area is expensive and measurements are rather difficult to make because of weather conditions. Satellites are also blinded by the presence of sea ice during nine months and only recent Argo floats can make measurements below sea ice (Klatt et al., 2007). Thus, the modelling tools can play a major role in improving our understanding of the oceanic circulation in this area.

In this modelling study, we first evaluate the ability of the ocean-sea ice model NEMO (Madec, 2008) to simulate the main characteristics of the ASC, underlining the importance of having a sufficiently high resolution in the ocean and examining the sensitivity of the ASC transport to the atmospheric forcing. Our second objective is to determine the processes governing the seasonal cycle of the ASC. The paper is organized as follows. Section 2 provides a description of the experimental design. In Sect. 3, we compare the characteristics of the ASC simulated by the model for different resolutions. Results of this section are used to estimate the minimal resolution required to reproduce the main characteristics of the ASC. This resolution is used in the regional model employed in the sensitivity experiments described in Sect. 4. In this part, the response of the ASC to different atmospheric forcing fields is analyzed, sorting out the effect of wind and temperature on the annual characteristics and seasonal variability of the ASC. Concluding remarks are finally given in Sect. 5.

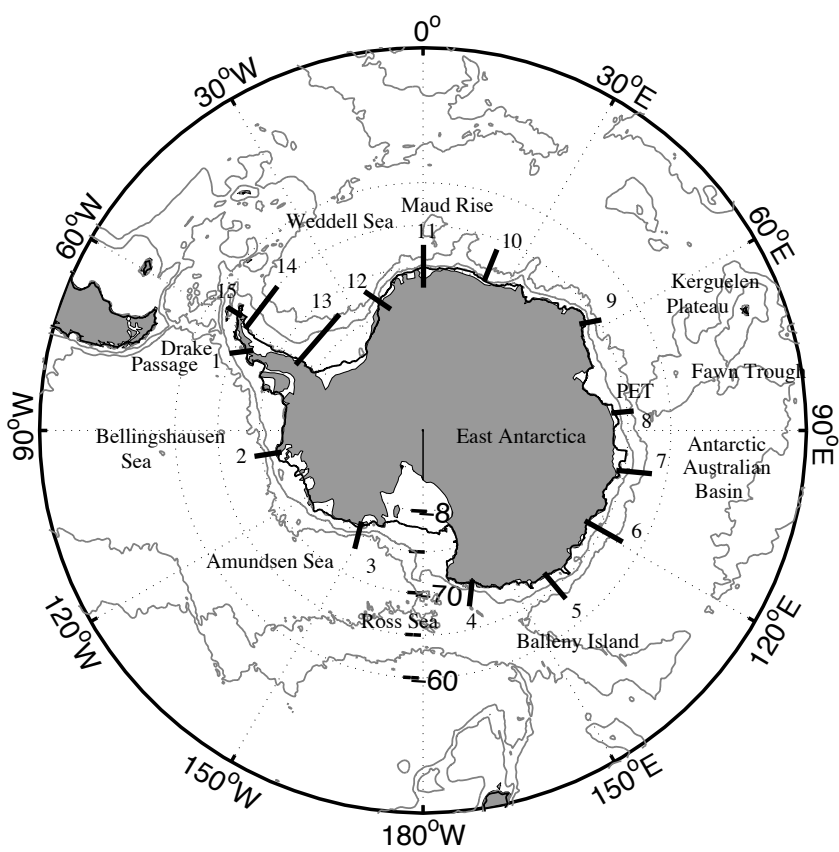

Fig. 1. Sections that are analyzed in the following figures (Figs. 11, 12 and 13). The grey lines correspond to bathymetry (1000 $\mathrm{m}$ and $3500 \mathrm{~m}$ ). The effective offshore limit for the plots in all the sections and all the simulations is the $3500 \mathrm{~m}$ bathymetry line.

\section{Experimental design}

This section briefly describes the ocean-sea ice model, the model configurations and the atmospheric forcing fields used in this study.

\subsection{Ocean-sea ice general circulation model}

The ocean-sea ice general circulation model is NEMO $(\mathrm{Nu}-$ cleus for European Modelling of the Ocean; Madec, 2008), which derives from the primitive equation, free surface ocean model OPA9 (Océan PArallélisé) coupled to the second version of the Louvain-la-Neuve sea ice model (LIM2; Fichefet and Morales Maqueda, 1997). The surface boundary layer mixing and interior vertical mixing are parameterized according to a turbulent kinetic energy closure scheme (see NEMO reference manual; Madec, 2008). The bottom boundary layer parameterization is based on Beckmann and Döscher (1997). The bottom topography is represented as partial steps. Note that cavities under ice shelves are not represented or parameterized in the model. Bulk formulas provided by Large and Yeager (2004) are used to compute both momentum and heat fluxes over the ocean. Over sea ice, the transfer coefficients are fixed to $1.63 \times 10^{-3}$ for momentum and heat. In this study, two configurations of NEMO are used: a global one and a regional one. 


\subsection{Model configurations}

\subsubsection{Global configuration}

The global configuration (named ORCA) of the NEMO model is based on a family of tripolar grids, ORCA grids. The geographical South Pole is conserved and from $80^{\circ} \mathrm{S}$ to $20^{\circ} \mathrm{N}$, the grid is a regular Mercator grid (isotropic, getting finer at high latitude as the cosine of latitude). Following Murray's (1996) idea, the singularity of the North Pole is treated by changing the coordinate system using two poles. The grid is computed following the semianalytical method of Madec and Imbard (1996).

The ORCA configurations (shared by the ocean and sea ice models) selected here have an effective resolution, which gets finer with increasing latitudes, of $\sim 222 \mathrm{~km}\left(2^{\circ}\right.$ resolution, ORCA2), $\sim 111 \mathrm{~km}\left(1^{\circ}\right.$ resolution, ORCA1), $\sim 55.5 \mathrm{~km}$ $\left(0.5^{\circ}\right.$ resolution, ORCA05) and $\sim 27.8 \mathrm{~km}\left(0.25^{\circ}\right.$ resolution, ORCA025) at the equator. The grid is finer at $60^{\circ} \mathrm{S}$ (e.g. $\sim 13.8 \mathrm{~km}$ in ORCA025). The vertical resolution comprises 46 levels unequally spaced $(6 \mathrm{~m}$ near the surface and $200 \mathrm{~m}$ near the bottom). Initial conditions for temperature and salinity are derived from the Levitus et al. (1998) data set for the low and middle latitudes. For high latitudes, we chose the Polar science center Hydrographic Climatology (PHC2.1; Steele et al., 2001). All the details of the ORCA setup at $0.25^{\circ}$ (ORCA025) are given in Barnier et al. (2006). The same characteristics are used for simulations carried out at $2^{\circ}, 1^{\circ}, 0.5^{\circ}$ and $0.25^{\circ}$ resolution. These simulations are used to evaluate the sensitivity of the ASC to the model resolution and are named ORCA2, ORCA1, ORCA05, ORCA025, respectively. Results of this comparison are employed to design the regional configuration used to evaluate the sensitivity of the forcing fields to the model resolution.

\subsubsection{Regional configuration}

The regional configuration is based on the global one. It is limited to the Southern Ocean and its northern boundary is located at $30^{\circ} \mathrm{S}$. Radiative open boundary conditions, inherited from the work of Treguier et al. (2001), are used at the lateral limits of the domain for the oceanic variables.

The initial and open boundary conditions of this configuration are provided by the 5-day outputs of a global oceansea ice model simulation carried out with the corresponding global ORCA model configuration. The resolution used in this study is $0.5^{\circ}\left(22 \mathrm{~km}\right.$ at $\left.66^{\circ} \mathrm{S}\right)$, and the model setup is the same as the ORCA05 one.

\subsection{Atmospheric forcing fields}

Two different forcing data sets are used to drive the model configurations. The first one is the Drakkar Forcing Set 3 (DFS3; Brodeau et al., 2010), which was used in hindcast simulations performed over the last decades with the four global configurations (ORCA2, ORCA1, ORCA05, ORCA025; Penduff et al., 2010) and in the regional configuration (Mathiot et al., 2009). In this study, the DFS3 forcing is used in the global configuration as in the regional configuration. The second one is provided by a dynamical downscaling of the ECMWF 40 Year Re-analysis (ERA40; Simmons and Gibson, 2000) by the regional atmospheric model MAR (Modèle Atmosphérique Régional; Gallée and Schayes, 1994). This forcing is only used with the regional configuration.

\subsubsection{DFS3 forcing}

The DFS3 forcing combines elements of the CORE (Common Ocean-ice Reference Experiments) forcing data set of Large and Yeager (2004) with atmospheric state variables from ERA40 reanalysis. As described in details in Brodeau et al. (2010), the DFS3 atmospheric variables required by NEMO are (i) from CORE: monthly precipitation rates (rain and snow), daily downward shortwave and longwave radiations, all derived from satellite products, and (ii) from ERA40: $6 \mathrm{~h} 10 \mathrm{~m}$ wind speeds, air humidities and air temperatures (the turbulent fluxes in NEMO are calculated using bulk formulas of Large and Yeager, 2004). The spatial resolution is $1.125^{\circ}$ for ERA40 data and $1.875^{\circ}$ for CORE data. For the simulations conducted with this forcing, all atmospheric data are interpolated on the grid of the corresponding ocean-sea ice model configuration. Note that, to account for the effects of the katabatic winds around Antarctica, a correction is applied to the original DFS3 forcing. This correction is based on the results obtained with MAR applied over the Antarctic region. See Mathiot et al. (2010) for details.

\subsubsection{MAR forcing}

The second forcing comes directly from simulations carried out with the MAR model. MAR is a hydrostatic mesoscale atmospheric model based on the three dimensional primitive equations written in terrain following coordinates (Gallée and Schayes, 1994; Gallée, 1995; Gallée et al., 2005). The hydrological cycle component includes a cloud microphysical model, with conservation equations for cloud droplet, raindrop, cloud ice crystal and snowflake concentrations. The Antarctic ice sheet is assumed to be entirely covered with snow. A snow model (Brun et al., 1992) allows snow metamorphism (which affects surface energy fluxes). Blowing snow is also represented in the turbulent scheme (Gallée et al., 2001). The orographic roughness length is derived from the variance of the topography. This length has been tuned with the help of automatic weather station (AWS) data so that valleys in the Transantarctic Mountains are represented as well as possible (Jourdain and Gallée, 2011). The tuning of the orographic roughness length is a key point in order to get a good representation of katabatic winds. The grid is cartesian with an oblique polar stereographic projection. 
Table 1. Simulations description (resolution, forcing and configuration).

\begin{tabular}{|c|c|c|c|c|}
\hline & Configuration & Resolution & Wind forcing & Air temp. forcing \\
\hline ORCA2 & Global & $2^{\circ}$ & DFS3 & DFS3 \\
\hline ORCA1 & $"$ & $1^{\circ}$ & , & $"$ \\
\hline ORCA05 & ” & $0.5^{\circ}$ & ” & ” \\
\hline ORCA025 & ” & $0.25^{\circ}$ & " & $"$ \\
\hline REF & Regional & $0.5^{\circ}$ & DFS3 & DFS3 \\
\hline WIND & $"$ & ” & MAR & DFS3 \\
\hline TEMP & $”$ & 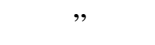 & DFS3 & MAR \\
\hline WIND + TEMP & $"$ & " & MAR & MAR \\
\hline SEASO & $”$ & " & MAR-seasonal cycle & MAR \\
\hline
\end{tabular}

The horizontal resolution is $40 \mathrm{~km}$ and the first vertical level is at $\sim 10 \mathrm{~m}$. Surface boundary conditions and lateral conditions at the open boundaries of the model domain are prescribed from ERA40 reanalyses. MAR is run over a period of ten years (1980-1989).

A comparison between MAR coastal dynamics and AWS data in some areas of the Ross Sea and along Antarctica has been performed by Mathiot et al. (2010), Jourdain and Gallée (2011) and Petrelli et al. (2008). All these studies show a good agreement between MAR outputs and AWS data in terms of barrier winds along Transantarctic Mountains and katabatic winds.

As MAR is not global, a merging of all the required atmospheric variables provided by MAR with the fields provided by DFS3 is performed. In this application, MAR covers a large part of the Southern Ocean, which includes the whole continental shelf and slope areas around Antarctica. The latitude of this merging is $63^{\circ} \mathrm{S}$. As MAR lateral boundary conditions are prescribed from ERA40, a small buffer zone of $2^{\circ}$ between DFS3 and MAR forcing fields is applied to smooth the transition and avoid outbreak of unrealistic oceanic features along the merging line.

\subsubsection{Comparison between MAR and DFS3 forcings}

The major differences between the two forcing fields are related to the horizontal resolution, the representation of orography and the turbulent scheme in the model. These differences lead to a better representation of barrier winds (along Transantarctic Mountains and along the Antarctic Peninsula) and katabatic winds in MAR. Usually blowing offshore perpendicular to the coast, katabatic winds are deflected to the left by the Coriolis force as they move over the ocean (or sea ice), driving strong easterlies along the coast of Antarctica (Davis and Mc Nider, 1997). As expected, MAR provides katabatic winds stronger than DFS3, and thus stronger easterlies (Mathiot et al., 2010). Easterlies have also a larger seasonal cycle, with weaker winds during summer and stronger winds during autumn in MAR than in DFS3 (Fig. 2), in agreement with the observations of Nunez-Riboni and Fahrbach (2009). The improved coastal wind dynamics and turbulence scheme in the MAR model lead to significant changes in surface air temperature along the coast compared to DFS3 (Fig. 3). Coastal temperatures are lower in MAR, up to $-8{ }^{\circ} \mathrm{C}$ at $70^{\circ} \mathrm{S}$ during winter. During summer, differences between MAR and DFS3 temperatures are weaker (up to $-3{ }^{\circ} \mathrm{C}$ at $70^{\circ} \mathrm{S}$ ). This lower difference during summer is mainly due to the prescription of the surface temperature to the melting point when sea ice melts. For further details about the differences between MAR with DFS3 forcing fields, see Mathiot et al. (2009).

\subsection{Experimental setup}

To study the sensitivity of the ASC to the model resolution and atmospheric forcing, two series of simulations are conducted. The first one corresponds to global simulations performed in ORCA configuration (Penduff et al., 2010) at four resolutions over the last 50 years (Table 1$)$ : $2^{\circ}$ (ORCA2), $1^{\circ}$ (ORCA 1 ), $0.5^{\circ}$ (ORCA05) and $0.25^{\circ}$ (ORCA025). All these simulations use the DFS3 forcing fields. The second series of simulations are performed over the period 1980-1989 and use the regional configuration of the model with a resolution of $0.5^{\circ}$. In this series, four experiments (in addition to the reference simulation named REF) are carried out. In each experiment, only one component of the forcing is changed (Table 1).

The reference simulation (REF) is the regional version of ORCA05. In simulation named WIND, the wind forcing (air temperature and air humidity forcing) is provided by MAR (DFS3). In simulation TEMP, the wind forcing (air temperature and air humidity forcing forcing) is provided by DFS3 (MAR). The simulation WIND + TEMP is a combination of WIND and TEMP, the wind forcing, the air temperature forcing and the humidity forcing are provided by MAR. Thus, comparing REF with WIND simulations (or TEMP and WIND + TEMP) gives the sensitivity of the ASC transport to the wind forcing. Comparing REF and TEMP simulations (or WIND and WIND + TEMP) gives the sensitivity of ASC to the thermal forcing. In the simulation named 

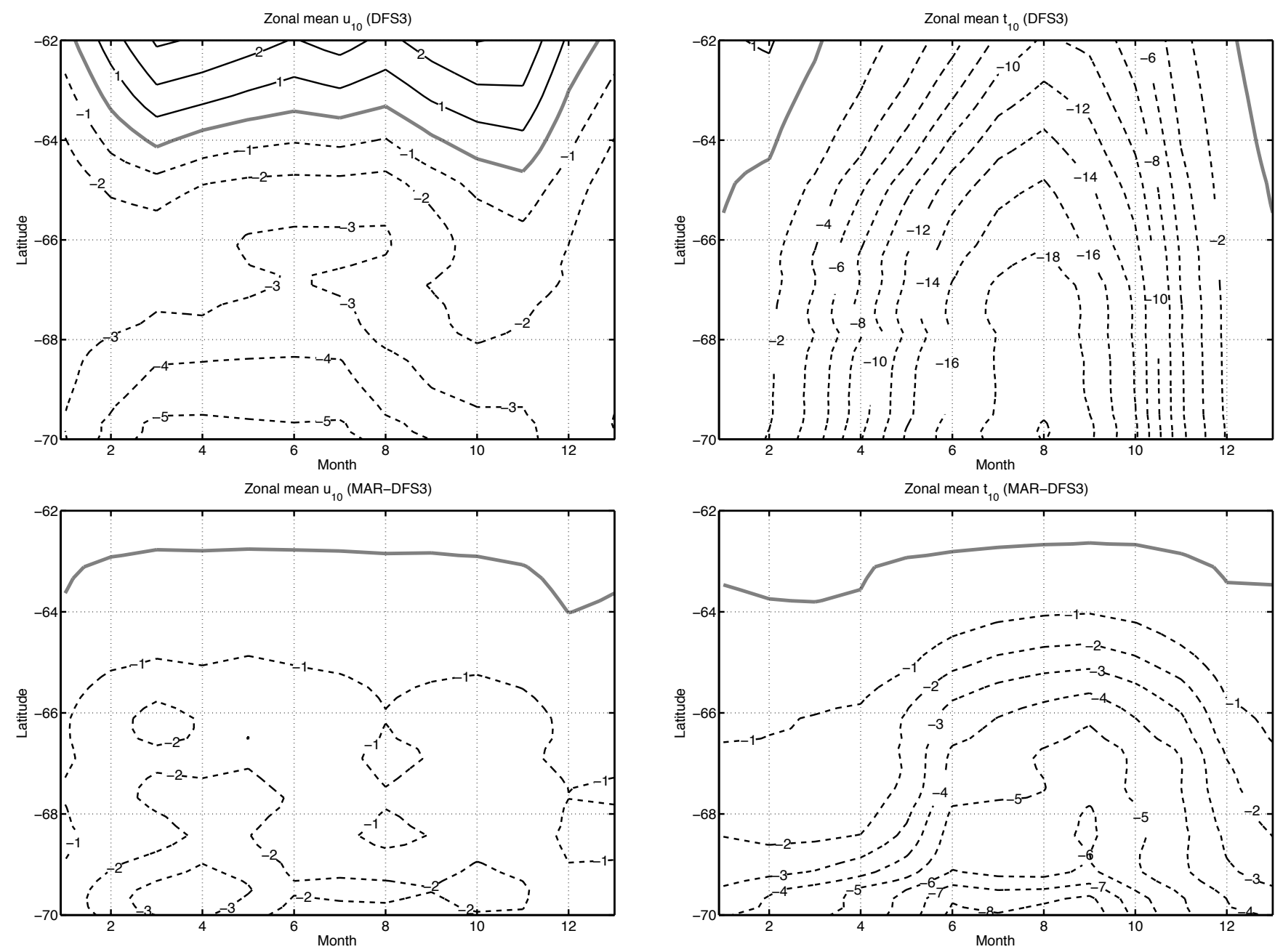

Fig. 2. Zonal average $\left(0^{\circ} \mathrm{E}-150^{\circ} \mathrm{E}\right)$ of the zonal mean component of the wind speed $\left(\mathrm{u}_{10}\right)$ over 1980-1989 in DFS3 (top) and of the difference of $\mathrm{u}_{10}$ between MAR and DFS3 (bottom). In the upper figure, black lines correspond to a westerly wind and black dashed lines to an easterly wind. In the lower figure, a black dashed line corresponds to a stronger easterly wind in MAR and the thick grey line corresponds to the 0 difference line.

SEASO, the climatological (1980-1989) seasonal cycle of the wind forcing provided by MAR is substituted by a climatological annual mean. This simulation is used to diagnose the effects of the seasonal cycle of the wind on the seasonal cycle of ASC. See Table 1 for the details of the experiments. Radiations and precipitations are the same in all these simulations. In the following part, simulation results are averaged over the common period 1985-1989.

\section{Sensitivity of the ASC to model resolution}

In order to choose the resolution needed in the wind sensitivity study, we assess, in this section, the ability of the coarse and high-resolution model configurations to simu-

Fig. 3. Zonal average $\left(0^{\circ} \mathrm{E}-150^{\circ} \mathrm{E}\right)$ of the mean surface air temperature $\left(\mathrm{t}_{10}\right)$ over 1980-1989 in DFS3 (top) and of the difference of $t_{10}$ between MAR and DFS3 (bottom). Top: the thick grey lines correspond to the $0{ }^{\circ} \mathrm{C}$ isotherm. Bottom: the thick grey lines correspond to the 0 line, and negative values (dashed lines) mean a colder atmosphere in MAR.

late the main features of the ASC. A general overview of the model performance in the Southern Ocean area is given in Table 2 for the four configurations. Other studies provide a complementary evaluation of ORCA simulations in the Southern Ocean (Lachkar et al., 2007), Biastoch et al., 2008a, b and Penduff et al., 2010 for ORCA05; Renner et al., 2009 and Treguier et al., 2007 for ORCA025). Regarding sea ice, all ORCA simulations exhibit the same biases, i.e. a lack of sea ice extent in summer and an excess in winter. The lack of ice during summertime seems to be due to too warm forcing fields (Table 2, simulations TEMP and WIND + TEMP with a colder atmosphere lead as expected to more sea ice in summer). All simulations produce a reasonable transport trough Drake Passage ranging 
between 117 and $147 \mathrm{~Sv}$, against $137 \pm 8 \mathrm{~Sv}$ in the observations of Cunningham et al. (2003). A comparison of ORCA results with estimates of Klatt et al. (2005) indicates that ORCA2 and ORCA1 underestimate by more than $20 \mathrm{~Sv}$ the transport at the southern limb of the Weddell Gyre. By contrast, ORCA05 and ORCA025 overestimate this transport by 7 and $14 \mathrm{~Sv}$, respectively. Overall, the simulation results are consistent with what we know of the primary large-scale features of the Southern Ocean. The ability of the global configurations of the model to simulate the ASC is first evaluated along the east coast of Antarctica, from $160^{\circ} \mathrm{E}$ to $50^{\circ} \mathrm{E}$. The coast and the bathymetry of this sector have the particularity to be almost zonal and the oceanic circulation has been observed during summer by two oceanographic surveys: BROKE EAST and BROKE WEST (Meijer et al., 2010; Bindoff et al., 2000). Along this coast, the ASC is a continuous current (Meijer et al., 2010; Bindoff et al., 2000), with recirculation along the Kerguelen Plateau (Mac Cartney and Donohue, 2007; Park et al., 2009).

The zonal transport associated with this current along the Antarctic coast varies significantly between simulations (Figs. 4, 5 and 6). ORCA2 has a very weak ASC between $160^{\circ} \mathrm{E}$ and the Princess Elisabeth Trough (PET; longitude of PET is between $85^{\circ} \mathrm{E}$ and $80^{\circ} \mathrm{E}$ ). The ASC is blocked by the presence of the PET and is then absent west of $80^{\circ} \mathrm{E}$ in the model. In ORCA1, the ASC is better represented. Its strength increases from 2 to $15 \mathrm{~Sv}$ between $150^{\circ} \mathrm{E}$ and $90^{\circ} \mathrm{E}$. The PET strongly impedes its flow $(-85 \%)$. After crossing the PET, the ASC intensifies through incorporation of the westward flowing southern branch of the Weddell Gyre. In these two configurations (ORCA2 and ORCA1), PET has a very strong impact on the flow. Clearly, observations do not show such a decrease of ASC transport through PET. The ASC is also weaker in ORCA2 and ORCA1 simulations than in the observations. For example, at $110^{\circ} \mathrm{E}$, Bindoff et al. (2000) report a total westward transport of $30 \mathrm{~Sv}$, compared to 1 and $9 \mathrm{~Sv}$ in ORCA2 and ORCA1, respectively. At $80^{\circ} \mathrm{E}$, a transport of $16 \mathrm{~Sv}$ is observed compared to 0 and $2 \mathrm{~Sv}$, in ORCA2 and ORCA1, respectively.

In ORCA05 and in ORCA025, the total westward transport associated with the ASC is higher, and a significant transport of the ASC is simulated through the PET (Fig. 4). In ORCA05, the ASC flow increases between $140^{\circ} \mathrm{E}$ to $90^{\circ} \mathrm{E}$ from 9 to $28 \mathrm{~Sv}$ (gyre recirculation). The recirculation along the Kerguelen Plateau is estimated to be $14 \mathrm{~Sv}$ (56\% of initial ASC). After crossing the PET, the ASC transport amounts to about $15 \mathrm{~Sv}$. Between $80^{\circ} \mathrm{E}$ and $60^{\circ} \mathrm{E}$, this transport increases and then decreases by $4 \mathrm{~Sv}$. This is the signature of the small Prydz Bay gyre observed by Nunes Vaz and Lennon (1996). Afterwards, the ASC enters the Weddell Gyre. Then, the total westward transport strongly increases west of $60^{\circ} \mathrm{E}\left(+13 \mathrm{~Sv}\right.$ in ORCA05 between $60^{\circ} \mathrm{E}$ and $50^{\circ} \mathrm{E}$ ). This description fits well with that proposed by Bindoff et al. (2000) and Meijers et al. (2010) based on data collected during the oceanographic campaign BROKE.

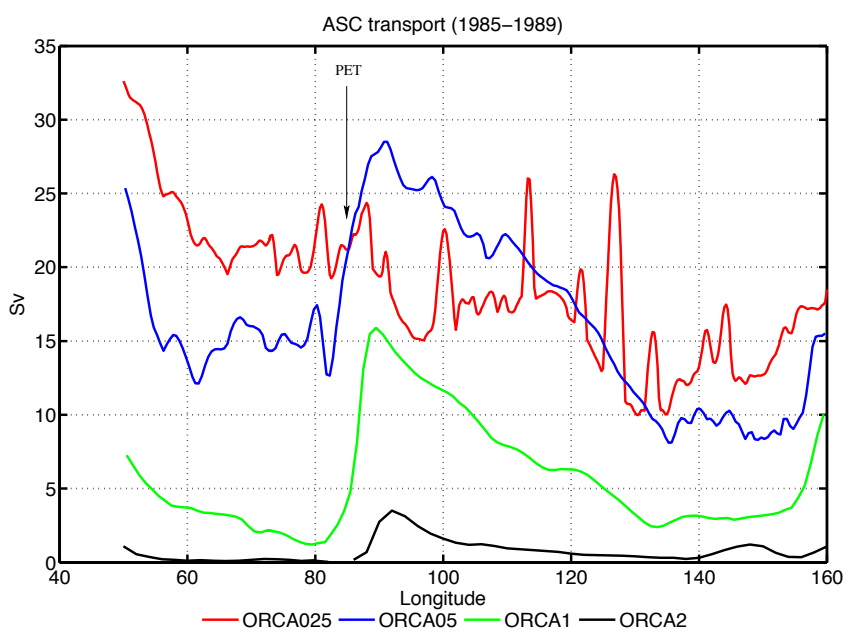

Fig. 4. Maximum cumulative westward transport from the coast to $61^{\circ} \mathrm{S}$ between $50^{\circ} \mathrm{E}$ and $160^{\circ} \mathrm{E}$ in February. Choice of $61^{\circ} \mathrm{S}$ has been done to avoid recirculation along bathymetry features like the Kerguelen Plateau. Each color (red, blue, green and black) corresponds to one resolution (ORCA025, ORCA05, ORCA1 and ORCA2). ASC flow comes in at $160^{\circ} \mathrm{E}$ (right side of the plot) and comes out at $50^{\circ} \mathrm{E}$ (left side of the plot). "PET" corresponds to the location of the Princess Elisabeth Trough.

In ORCA025, the ASC has a different behavior than in the other simulations. The transport does not increase continuously between $140^{\circ} \mathrm{E}$ and $90^{\circ} \mathrm{E}$ as in ORCA2, ORCA1 or ORCA05. The mean transport in this area is also lower than in ORCA05. The wide gyre between $135^{\circ} \mathrm{E}$ and $100^{\circ} \mathrm{E}$ simulated in ORCA05 is smaller in ORCA025 (7 Sv). Furthermore, the ASC transport presents many large peaks due to stationary eddies in the Australian Antarctic Basin (Fig. 4). As far as the PET is concerned, there is no recirculation along the Kerguelen Plateau in ORCA025. All the flow crosses the PET. This feature is characteristic of one large gyre (Weddell Gyre merged with Australian Antarctic Gyre), while two are present in the observations (Roquet, 2009). In the Fawn Trough on the Kerguelen Plateau (Fig. 1), ORCA05 is also better than ORCA025. A flow across this passage is observed at $43 \mathrm{~Sv}$ (Park et al., 2009). ORCA05 simulates a transport of $39 \mathrm{~Sv}$. ORCA025 underestimates this transport (29 Sv) as shown in Table 2. Simulations carried out with a regional model based on ORCA025 in the Kerguelen Plateau area (Roquet, 2009) indicate that the representation of the details of bathymetry, which are related to the resolution, has a large impact on the oceanic circulation simulated. The number and intensity of the spurious stationary eddies present in the Antarctic-Australian basin using in simulation using a raw bathymetry (instead of a smoothed bathymetry as in the present study; Figs. 4, 5 and $6 \mathrm{~b}$ ) are lower, with lower intensity. With such a raw bathymetry, the transport of the Antarctic Australian gyre and the transport across the Fawn Trough both increase by $5 \mathrm{~Sv}$. We conclude that many of the 
Table 2. Sea ice extent, zonal transport through Drake Passage, through Weddell Gyre along the Greenwich Meridian and through Fawn Trough for all simulations (period 1985-1989). The definition of the sea ice extent used here is the area where sea ice concentration is greater than $15 \%$. Observations come from Fetterer and Knowles 2004) (SSMI data) for sea ice extent, from Cunningham et al. (2003) for transport through Drake Passage, from Klatt et al. (2005) for the transport in the Weddell Gyre along the Greenwich Meridian and from Park et al. (2009) for the transport across Fawn Trough.

\begin{tabular}{lccccc}
\hline Simulation & $\begin{array}{c}\text { Sea ice extent } \\
\left(\text { million } \mathrm{km}^{2}\right) \\
\text { March }\end{array}$ & $\begin{array}{c}\text { Transport across } \\
\text { September }\end{array}$ & $\begin{array}{c}\text { Transport across } \\
\text { Deddell Gyre (Sv) }\end{array}$ & $\begin{array}{c}\text { Transport across } \\
\text { Fawn Trough (Sv) }\end{array}$ \\
\hline ORCA2 & 2.1 & 18.8 & 142 & 24 & 46 \\
ORCA1 & 2.7 & 21.3 & 147 & 33 & 45 \\
ORCA05 & 1,1 & 20.0 & 129 & 65 & 39 \\
ORCA025 & 1.1 & 20.4 & 117 & 69 & 29 \\
REF & 1.5 & 20.2 & 130 & 63 & 38 \\
TEMP & 5.4 & 20.5 & 132 & 61 & 38 \\
WIND & 1.6 & 20.2 & 125 & 68 & 38 \\
WIND + TEMP & 4.8 & 20.5 & 126 & $56 \pm 8$ & 43 \\
Observations & 2.5 & 18.5 & $137 \pm 8$ & & \\
\hline
\end{tabular}

biases observed in the ORCA025 results are likely artifacts resulting from the treatment of bathymetry.

The northern boundary of the ASC is interpreted here as the northernmost model point with a westward flow. Observations of Orsi et al. (1995) are in agreement with the simulated northern boundary of the ASC in ORCA1 and ORCA05 (Fig. 5). In ORCA2, the absence of ASC in many sectors is the main cause of discrepancy with observations. In ORCA025, the boundary is too southwards on the east side of Kerguelen Plateau and too northwards on the west side of this plateau. These differences are due to an underestimation of the Antarctic Australian gyre (East of Kerguelen Plateau) and an overestimation of Weddell Gyre transport (west of Kerguelen plateau), respectively.

The comparison of the ORCA2, ORCA1, ORCA05 and ORCA025 results with oceanographic data suggests that resolutions of $2^{\circ}$ and $1^{\circ}$ are not high enough to simulate the ASC (typical resolution of climate model, Randall et al., 2007). We need a resolution of at least $0.5^{\circ}$ (about $23 \mathrm{~km}$ at $65^{\circ} \mathrm{S}$ ) to catch the main features of ASC. At higher resolution (ORCA025), Ross Gyre and Weddell Sea Gyre are well represented and are comparable to the ORCA05 ones (Fig. 6). However the absence of Antarctic Australian Gyre and the presence of stationary eddies are not realistic. Thus ORCA025 simulation could not be used in this study. These eddies seems to be due to representation of bathymetry in this area and this point has to be improved to simulate well the circulation across the Kerguelen Plateau (PET and Fawn Trough) and in the Antarctic Australian basin.

Because of the most consistent results and its affordable computational cost, the resolution of $0.5^{\circ}$ is kept in the next section to study the impact of the atmospheric forcing on the ASC with a regional model. A circumpolar overview of the
ASC is given for this resolution (Fig. 6a) for the best simulation ORCA05. The four main gyres seen in the observations (Gouretsky, 1999; McCartney and Donohue, 2007; Nunez Vaz and Lennon, 1996; Klatt et al., 2005) are well represented (the Ross Gyre at roughly $150^{\circ} \mathrm{W}$, the Antarctic Australian Gyre at $90^{\circ} \mathrm{E}$, the small Prydz Bay Gyre at $75^{\circ} \mathrm{E}$ and the Weddell Gyre at $0^{\circ} \mathrm{E}$ ) and transports across typical sections and in gyres $\left(0^{\circ} \mathrm{E}\right.$, Fawn Trough, Antarctic Australian gyre, Drake) presented in Table 2 are realistic.

\section{Sensitivity of the ASC to model forcing}

In this section, we investigate the influence of the atmospheric forcing on the simulated ASC. The two forcing fields considered here are quite different but they are both realistic. All the experiments are run over 10 years (1980-1989), but only the results of the last 5 years are discussed (Table 1).

\subsection{Effect of different atmospheric variables on the ASC transport}

Three different simulations are performed using forcing fields derived from MAR results (Table 1). The comparison with the reference simulation (REF) gives an estimation of the effect of the turbulent components of the atmospheric forcing fields on the ASC: (i) wind speed (comparison between WIND and REF simulations), separately, (ii) the air temperature and air humidity (comparison between TEMP and REF simulations), and (iii) all of them together (comparison between WIND + TEMP and REF simulations). First of all, the main features obtained in these simulations are similar to those present in ORCA05 (see Table 2). However, discrepancies are noticed regarding summer sea ice extent and 


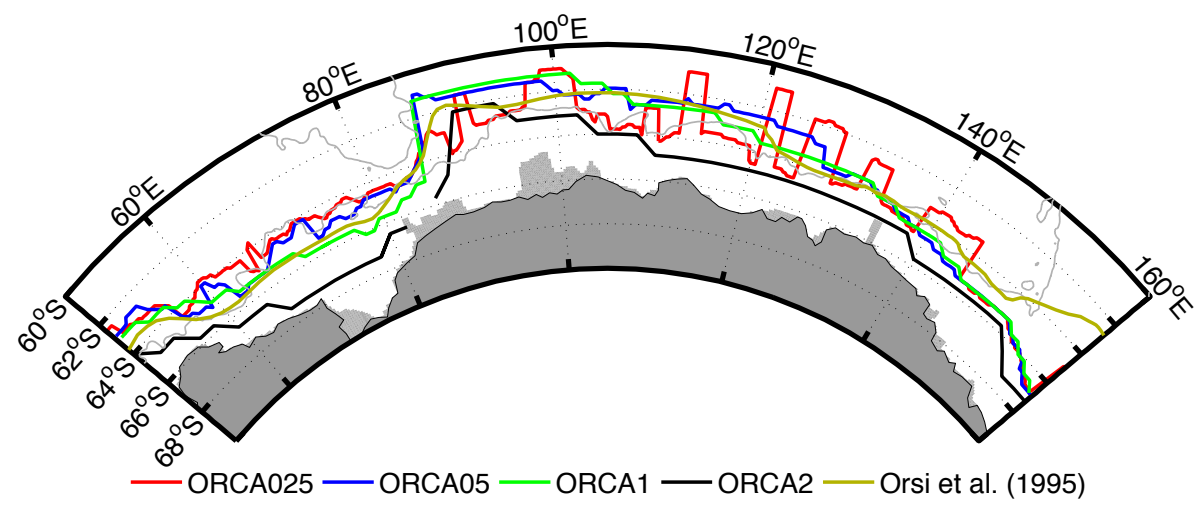

Fig. 5. Position of the maximum cumulative westward transport (Northern limit of the ASC) along the East Antarctic coast between $50^{\circ} \mathrm{E}$ to $160^{\circ} \mathrm{E}$. The grey line corresponds to the bathymetry line $3500 \mathrm{~m}$. The color code used is the same as in Fig. 3. The brown line represents the southern boundary of the ACC (northern boundary of the ASC) provided by Orsi et al., (1995). Presence of peaks in ORCA025 is due to the existence of stationary eddies in the model.
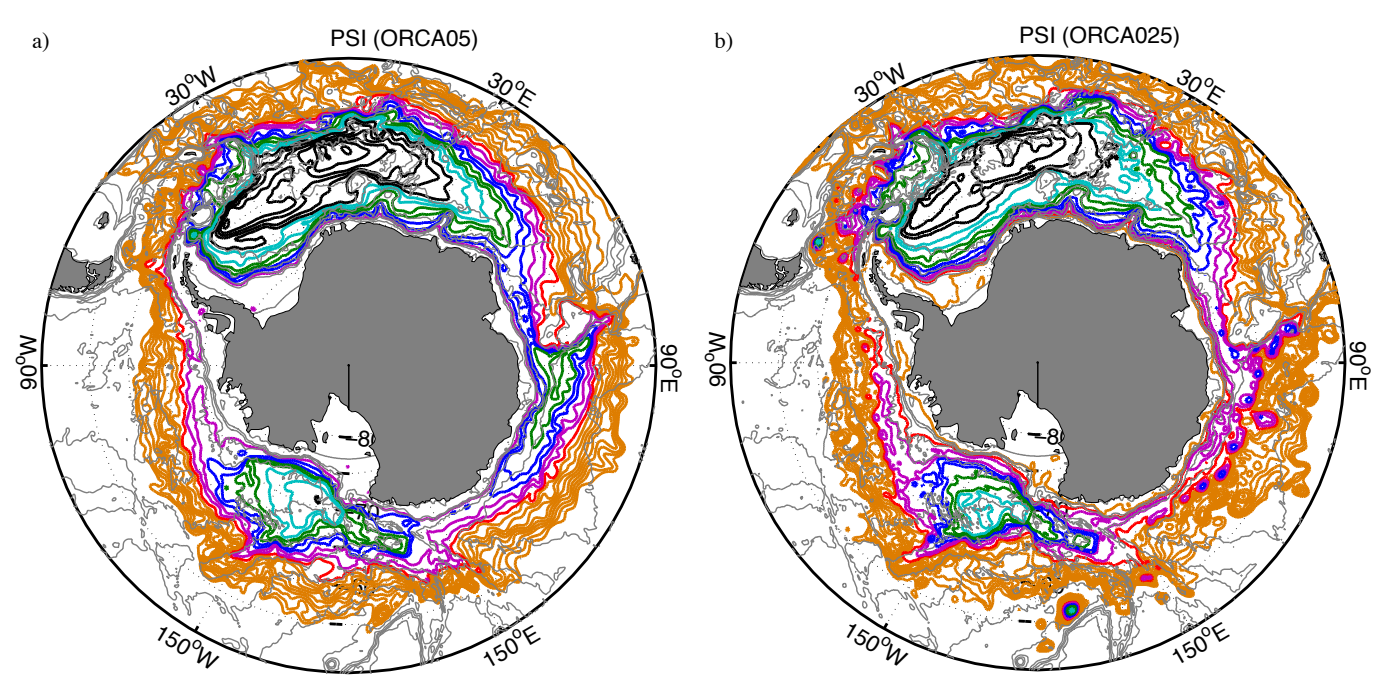

Fig. 6. Annual streamlines in the Southern Ocean for ORCA05 (a) and for ORCA025 (b). Step between two lines is 5 Sv. The ASC is defined here by the southern part of the gyres. Gray lines correspond to bathymetry (plotted each $1000 \mathrm{~m}$ ).

the Weddell Gyre transport. As sea ice is strongly dependent on the atmospheric forcing field, a colder forcing leads to an increase in sea ice extent during summer in TEMP and WIND + TEMP. During winter, the sea ice extent is almost the same in all simulations (Table 2). However, simulations with the lower air temperatures in MAR induce a thicker sea ice (Mathiot et al., 2009).

Our study is focused on the zonal circulation and hydrography of the Antarctic shelf and continental slope. In previous study, Klatt et al. (2005) observed, along a section at $0^{\circ} \mathrm{E}$ across the continental slope during 4 years (1996 to 2000), a strong current (more than $10 \mathrm{~cm} \mathrm{~s}^{-1}$ ) between the surface and $700 \mathrm{~m}$, with a maximum of $20 \mathrm{~cm} \mathrm{~s}^{-1}$ close to Antarctica coast. The analysis of the model results reveals that all our simulations produce a wider (about $1^{\circ}$ ) and slower current (between $5 \mathrm{~cm} \mathrm{~s}^{-1}$ and $15 \mathrm{~cm} \mathrm{~s}^{-1}$ ) in this area. Fur- thermore, this current (defined by the velocities $10 \mathrm{~cm} \mathrm{~s}^{-1}$ in the following discussion) is not deep enough in WIND and WIND + TEMP simulations ( $\sim 500 \mathrm{~m}$ in these simulations), and in TEMP and REF simulations ( $\sim 200 \mathrm{~m}$ in these simulations), as shown in Fig. 7. Similar features are also noticed in the section $60^{\circ} \mathrm{E}$ observed by Meijer at al. (2010) (not shown).

The velocity and depth of ASC exhibit a clear seasonal cycle (Figs. 7 and 8). During January (minimum of westward transport), the current is centered on the continental slope (69.5 to $\left.68.5^{\circ} \mathrm{S}\right)$. The depth of this current is $\sim 300 \mathrm{~m}$ in REF and TEMP (isoline $10 \mathrm{~cm} \mathrm{~s}^{-1}$ ) and $\sim 600 \mathrm{~m}$ in WIND and WIND + TEMP. During June (maximum of westward transport), the current is deeper, $\sim 1500 \mathrm{~m}$ in simulations carried out with MAR winds (WIND and WIND + TEMP) and $\sim 800 \mathrm{~m}$ in REF and TEMP (Fig. 8 ). The maximal velocity 

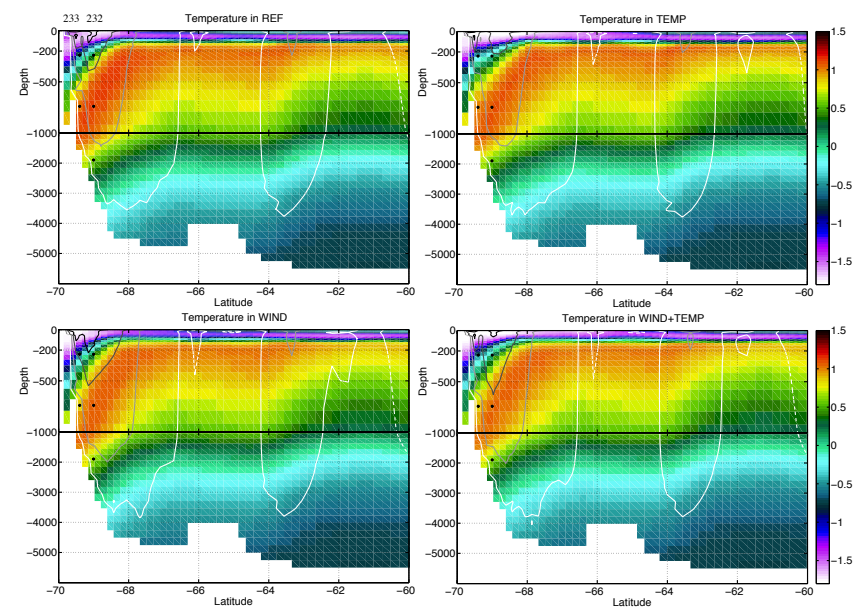

Fig. 7. Section at $0^{\circ} \mathrm{E}$ in simulations TEMP, REF, WIND and WIND + TEMP during January. Colors represent the temperature (in ${ }^{\circ} \mathrm{C}$ ) and solid lines represent the zonal current $\left(1 \mathrm{~cm} \mathrm{~s}^{-1}\right.$ is in white, $5 \mathrm{~cm} \mathrm{~s}^{-1}$ is in light grey, $10 \mathrm{~cm} \mathrm{~s}^{-1}$ is in dark grey line, dashed lines correspond to eastward velocity). The white area corresponds to the ocean floor. Notice that the vertical scale is not linear; a zoom is done on the first $1000 \mathrm{~m}$. Black dots show the moorings AWI 233 and 232 used in Figs. 9 and 10.

is also enhanced. In WIND and WIND + TEMP, a strong current with velocity higher than $15 \mathrm{~cm} \mathrm{~s}^{-1}$ is observed in the first $500 \mathrm{~m}$ on the continental slope. In REF and TEMP, the highest velocity (more than $15 \mathrm{~cm} \mathrm{~s}^{-1}$ ) is localized in the first $300 \mathrm{~m}$. This underlines the strong influence of the forcing fields on both the depth and velocity of the ASC.

The annual view proposed by Klatt et al. (2005) shows a strong current (more than $20 \mathrm{~cm} \mathrm{~s}^{-1}$ ) close to the coast $\left(70^{\circ} \mathrm{S}\right.$ to $69^{\circ} \mathrm{S}$ ) with a maximum depth of $800 \mathrm{~m}$ (isoline $10 \mathrm{~cm} \mathrm{~s}^{-1}$ ). The northern boundary of this current is around $67.5^{\circ} \mathrm{S}$ (isoline $1 \mathrm{~cm} \mathrm{~s}^{-1}$ ). In all our simulations, the core of the simulated current is shifted $\left(0.5^{\circ}\right.$ northwards $)$ and the simulated northern boundary is shifted $1^{\circ}$ northwards. Furthermore, the cyclonic circulation observed around Maud Rise is not strong enough in our simulations (compared to Klatt's observations).

A detailed comparison of the mean seasonal cycles of zonal velocity in the different simulations (1985-1989) with the mean seasonal cycle provided by the current meters AWI 233 and 232 over the period 1996 to 2000 (black dot in Figs. 7 and 8) confirms and completes the previous discussion (Fig. 9). At the shelf break (AWI 233), all the simulations slightly underestimate the seasonal cycle of zonal velocity. REF and TEMP well simulate the summer velocity but underestimate the maximum velocity (June). In simulations WIND and WIND + TEMP, it is the opposite: the summer zonal velocity is overestimated and the winter zonal velocity is well represented. At $69^{\circ} \mathrm{S}$, on the continental slope, the observed ASC have an almost constant velocity between surface and $1900 \mathrm{~m}$ with a clear seasonal cycle (maximum
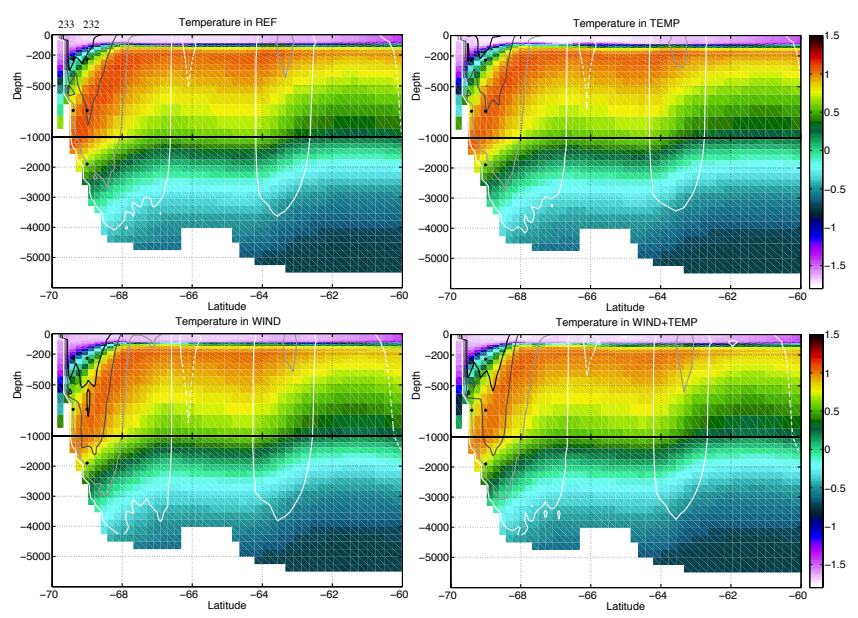

Fig. 8. Section at $0^{\circ} \mathrm{E}$ in simulations TEMP, REF, WIND and WIND + TEMP during June. Colors represent the temperature (in $\left.{ }^{\circ} \mathrm{C}\right)$ and lines represent the zonal currents $\left(1 \mathrm{~cm} \mathrm{~s}^{-1}\right.$ is in white, $5 \mathrm{~cm} \mathrm{~s}^{-1}$ is in light grey, $10 \mathrm{~cm} \mathrm{~s}^{-1}$ is in dark grey line, dash lines correspond to eastward velocity). The white area corresponds to the ocean floor. Notice that the vertical scale is not linear; a zoom is done on the first $1000 \mathrm{~m}$. Black dots show the moorings AWI 233 and 232 used in Figs. 9 and 10.

in June and minimum in December). In the four simulations the seasonal cycle is comparable to the observed one. However, the vertical shear of the ASC in all the simulations is larger than in the observations (more than $6 \mathrm{~cm} \mathrm{~s}^{-1}$ between surface and $1900 \mathrm{~m}$ depth) and the simulated zonal velocities are larger (up to $+10 \mathrm{~cm} \mathrm{~s}^{-1}$ in WIND during June).

The hydrographic structure of the ASF is almost the same in all simulations and seasons (Figs. 7 and 8). It is an "I shape" front (following the definition of Bindoff et al. (2000), i.e., the separation of water masses is roughly vertical). This shape is observed in many places, especially when a vein of Antarctic Bottom Water (AABW) is absent along the slope (Bindoff et al., 2000). In Klatt et al. (2005), the "I shape" is confirmed at $0^{\circ} \mathrm{E}$ as in the model results. A "V shape" front (following the definition of Bindoff et al., 2000, i.e., the separation of Circumpolar Deep Water, Antarctic Surface Water and Antarctic Bottom Water is roughly as a V), is observed in some sections but is not found in our simulations. This is due to processes, such as entrainment and mixing associated with dense outflows, that occur at scales too small for resolution in the ORCA05 model. See, e.g., Griffies et al. (2000).

The comparison of hydrographic properties derived from CTD data provided by AWI 233 and 232 moorings with the model results (Fig. 10) shows two behaviors. In surface, the seasonal cycle of water temperature and the temperature gradient between AWI 232 and AWI 233 is weaker in the four simulations than in the observations. At depth, the simulated temperature of the Antarctic Circumpolar Deep Water is too warm $\left(+0.6^{\circ} \mathrm{C}\right)$ along the continental slope and at the shelf break (AWI 232 and AWI 233). Comparison between our 

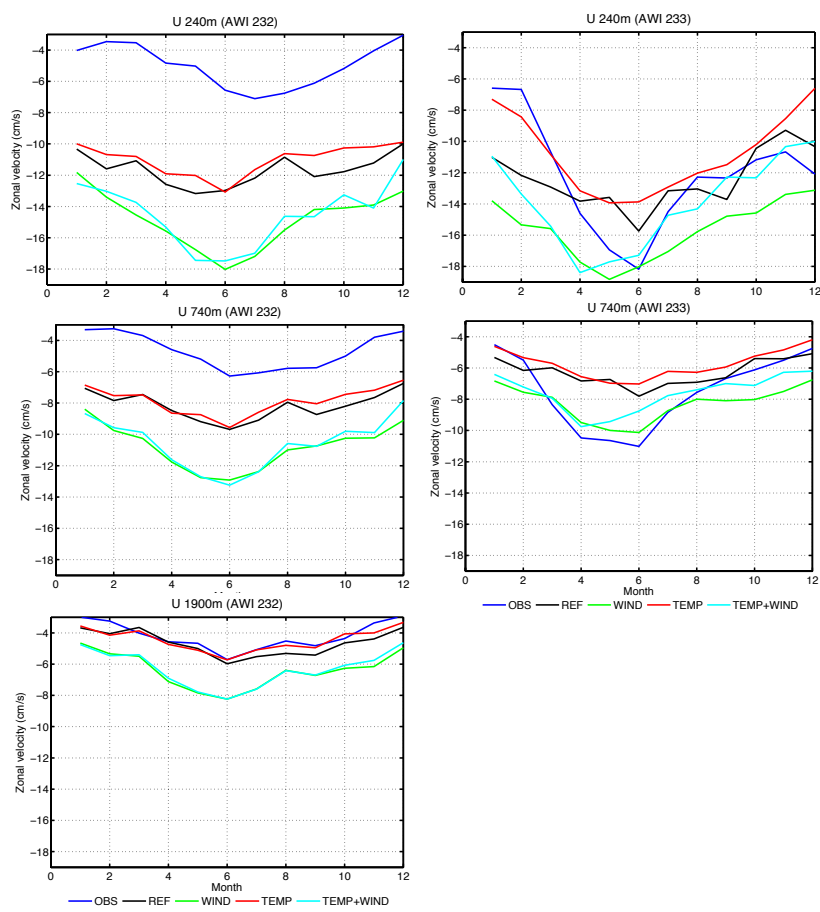

Fig. 9. Comparison of the mean zonal velocity at the AWI 233 and 232 moorings (see Figs. 7 and 8 for positions) simulated for each month and averaged over the period 1985-1989 (black line for REF, green line for WIND, red line for TEMP and cyan line for WIND + TEMP) and with observations over the period 1996-2000 (blue line).

simulations and the observed section $60^{\circ} \mathrm{E}$ in summer (Meijer et al., 2010) also shows a warmer water and a weaker temperature gradient (not shown). Mathiot et al. (2010) compare the temperature measured during the Broke East Hydrographic Survey between $150^{\circ} \mathrm{E}$ and $80^{\circ} \mathrm{E}$ (Bindoff et al., 2000) and ORCA05 simulation and they highlight also a too warm Circumpolar Deep Water (CDW) along the continental slope. Across the Weddell Sea, Renner et al. (2009) noticed the same biases along the Antarctic continental slope at $12^{\circ} \mathrm{W}$ and also across all the Weddell Sea in ORCA025 simulation. Clearly these biases in hydrographic properties affect the zonal velocity of the ASC in our simulations. Further hypotheses can be put forward to explain these hydrographic biases: a too low resolution to simulate strong temperature and density gradient, too low sea ice area during summer with DFS3 forcing (due to missing processes in sea ice model or to poor quality of forcing fields), too strong mixing of the HSSW with the CDW in the model and also poor representation of the Antarctic Shelf Water properties.

In Fig. 1, we present the locations where 15 different sections through which the annual integrated transport of the ASC is calculated. Values of this annual transport are given in Fig. 11. Each section extends from the coast to the bathymetry line $3500 \mathrm{~m}$ (which is the depth of PET). As
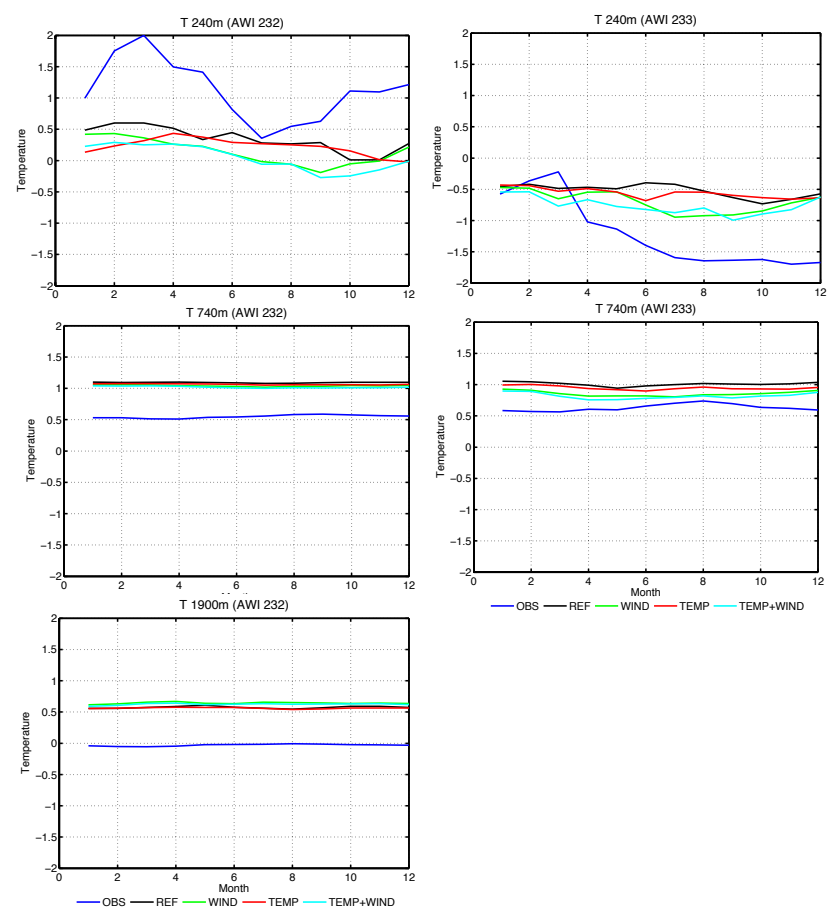

Fig. 10. Comparison of the mean temperature at the AWI 233 and 232 moorings (see Figs. 7 and 8 for position) simulated for each month and averaged over the period 1985-1989 (black line for REF, green line for WIND, red line for TEMP and cyan line for WIND + TEMP) with observations over the period 1996-2000 (blue line).

shown in Figs. 5, 7 and 8, this northern limit of the sections captures almost the entire ASC vein during all seasons (in January for the minimum and in June for the maximum). This boundary also avoids capturing part of the ACC transport in some simulations. However, with this method, the part of the ASC, which is flowing north of the bathymetry line $3500 \mathrm{~m}$ is not counted in our transport. The sections are distributed all along Antarctica from the west side of the Antarctic Peninsula (Sect. \#1) to Bransfield Straight at the tip of the Antarctic Peninsula (Sect.\#13). Along the west side of the Antarctic Peninsula (Sect. \#1), the Antarctic Circumpolar Current reaches the shelf (presence of an eastward current in Fig. 6 and Fig. 11). Consequently, ASC is absent in all simulations carried out (at least on the annual average). This is also the case in other observations and modelling studies (Beardsley et al., 2004; Martison et al., 2008; Pinones et al., 2010). Between the Bellingshausen and Amundsen Seas (Sect. \#2), a weak westward flow is noticed only in the REF and WIND simulations, which suggests an effect of the thermal forcing on the current direction in this area. Magnitude of this flow increases in magnitude from the Bellingshausen Sea to the Amundsen Sea (Sect. \#3) as in Holland et al. (2010). 


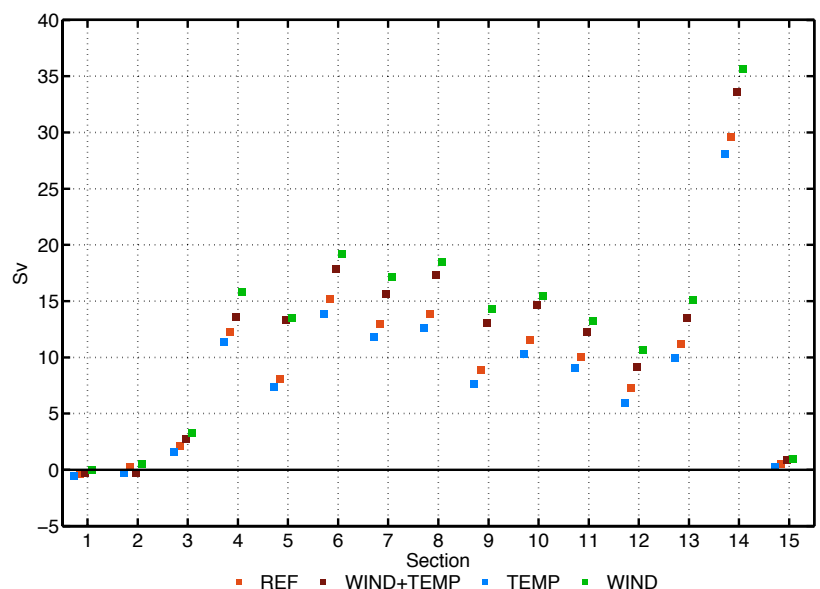

Fig. 11. Annual mean transport associated with the ASC in Sv across each section (horizontal axis) shown in Fig. 1 for TEMP (blue), REF (orange), WIND + TEMP (brown) and WIND (green).

In all the simulations, the ASC strengthens strongly to the west of the Ross Sea. The transport of ASC across the trough between Baleny Island and the Antarctic continent (Sect. \#4 in Fig. 11) has a value ranging between $11 \mathrm{~Sv}$ (TEMP simulation) and $16 \mathrm{~Sv}$ (WIND simulation), compared to $3 \mathrm{~Sv}$ at the entrance of the Ross Sea at $150^{\circ} \mathrm{W}$. Up to the PET, the strength of the ASC remains almost constant. A decrease of $5 \mathrm{~Sv}$ is then observed after the ASC crosses the PET (Sect. \#9 in Fig. 11). This decrease is due to the recirculation along the Kerguelen Plateau (Mc Cartney and Donohue, 2007) even for water masses present over a bathymetry shallower than the PET depth, as shown for ORCA05. After crossing the PET, the ASC is almost stable up to the base of the Antarctic Peninsula (Sect. \#13). However, in areas where the slope is very steep (\#12), the cumulated transport (between the coast and $3500 \mathrm{~m}$ depth line) slightly decreases. Along the Antarctic Peninsula (Sect. \#13 to \#14 in Fig. 11), the ASC transport strongly increases up to $27 \mathrm{~Sv}$ in TEMP and $34 \mathrm{~Sv}$ in WIND + TEMP. This increase is due to the presence of strong barrier winds along the Antarctic Peninsula and also due to a wide continental slope. After Sect. 14, almost all the flow turns east in the ACC and in the Weddell Gyre. A small part (less than $1 \mathrm{~Sv}$ ) turns west across the Bransfield Straight at the tip of Antarctic Peninsula (Fig. 11), as suggested by Heywood et al. (2004) and Von Gyldenfeldt et al. (2002).

On annual average, all sections (except the first one) show a stronger ASC transport in simulations performed with MAR winds (WIND and WIND + TEMP) compared to the similar simulations conducted with DFS3 winds (REF and TEMP). On the other hand, the ASC is weaker everywhere in simulations done with MAR temperature and humidity (TEMP and WIND + TEMP) compared to the similar simulations run with DFS3 temperature and humidity (REF and WIND). The increase in ASC transport due to the MAR

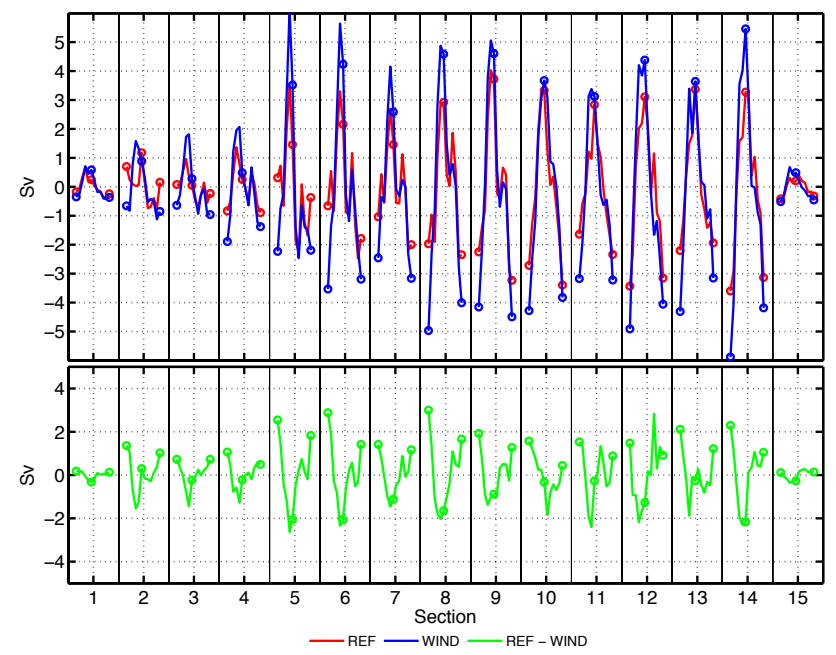

Fig. 12. The upper plot shows the anomaly of monthly ASC transport (compared to the annual mean transport of the ASC show in Fig. 11) across each section (horizontal axis) shown in Fig. 1. Each number corresponds to one section, and for each section, the circle on the left is January, then June and the circle on the right is December. The blue line is for WIND and the red line for REF. The bottom plot shows the difference between REF and WIND simulations (green line). A negative value means a stronger ASC in WIND simulation.

winds is about $40 \%$ along all the east coast of Antarctica, the decrease caused by temperature being less than $10 \%$ in the same area. This suggests that the wind is the most important atmospheric variable controlling the ASC transport between the surface and $2000 \mathrm{~m}$.

\subsection{Wind forcing of the seasonal cycle of the ASC}

Up to now, we have confirmed that the annual ASC transport is strongly influenced by the wind speed. As MAR and DFS3 winds have different seasonal cycles (see Figs. 2 and 3), the question now is: how does the seasonal cycle of the wind affect the seasonal cycle of the transport associated with the ASC?

To answer this question, we first analyze the seasonal cycle of the transport at the sections presented in Fig. 1. The results are displayed for both WIND and REF simulations (which only differ by the wind forcing) in Fig. 12.

This figure indicates that, in both simulations, the ASC transport has a strong seasonal cycle at all sections. Maximum transport is reached in May/June and minimum occurs in summer (December, January or February) as suggested by the observations of Nunez-Riboni and Fahrbach (2009) along the Fimbul iceshelf. As expected, the larger seasonal cycle of the easterlies in the MAR forcing lead to larger amplitude of the seasonal cycle of the ASC transport (Fig. 12) everywhere around Antarctica, especially along the coast of East Antarctica and in Weddell Sea. In these areas, the amplitude of the 


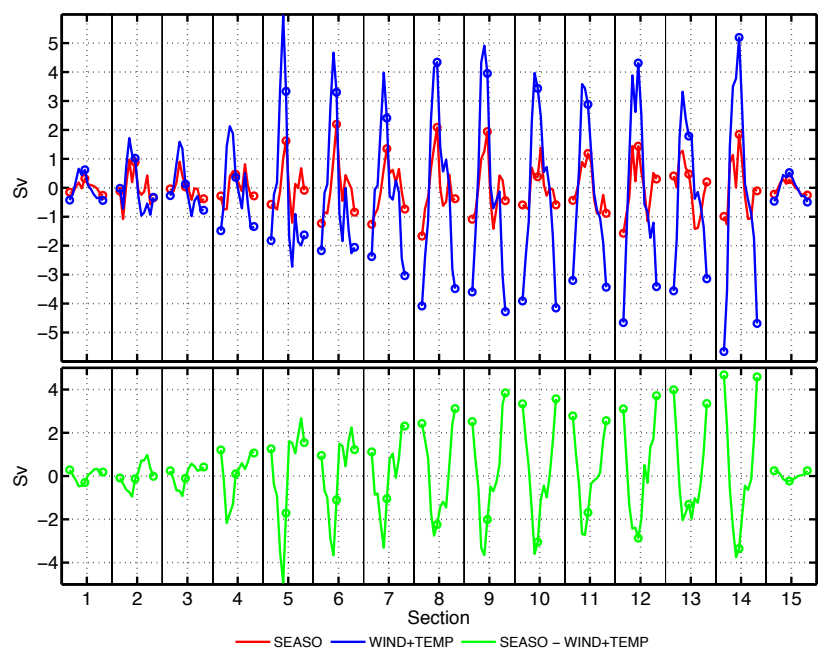

Fig. 13. Same as Fig. 12, but for SEASO and WIND + TEMP simulations.

seasonal cycle is larger by at least $2 \mathrm{~Sv}$ in WIND than in REF. In other words, this amplitude is increased by $30 \%$ when using the MAR wind fields. Figure 12 also shows that, during summertime, the flow along the west coast of the Antarctic Peninsula and in the Bellingshausen Sea becomes eastwards in the WIND and REF simulations.

To confirm the strong impact of the seasonality of the wind forcing on the seasonal cycle of the ASC, a comparison between WIND + TEMP and SEASO simulations is performed. SEASO is the same simulation as WIND + TEMP, but the seasonal cycle of each wind component over the period 1980-1989 is removed, the model being driven by the annual mean values of the wind speed over the same period and every other component of the atmospheric forcings being identical. Fig. 13 reveals that the absence of seasonal cycle leads to a decrease in the amplitude of the ASC seasonal cycle, in all sections, by at least $50 \%$.

A small residual seasonal cycle is however still present (from 1 to $2 \mathrm{~Sv}$ ). This feature could be caused by the seasonal variations of (1) the drag coefficient used to compute the wind stress and heat fluxes over the ocean, (2) the presence of sea ice and (3) the variability of water mass properties on the continental shelf and slope.

This strong sensitivity of the ASC to wind seems to be a direct consequence of the change in sea surface height along the Antarctic coast via Ekman drift. Sea Surface Height (SSH) along the Antarctic coast is higher in the simulations with stronger easterlies (WIND + TEMP and WIND), and almost the same in open ocean (north of $63^{\circ} \mathrm{S}$ for the east coast) as shown in Fig. 14. This leads to a higher pressure gradient between the coast and the open ocean in WIND (and WIND + TEMP) than in REF (and TEMP). As a consequence, the transport of ASC is higher in WIND (and WIND + TEMP) than in REF (and TEMP).

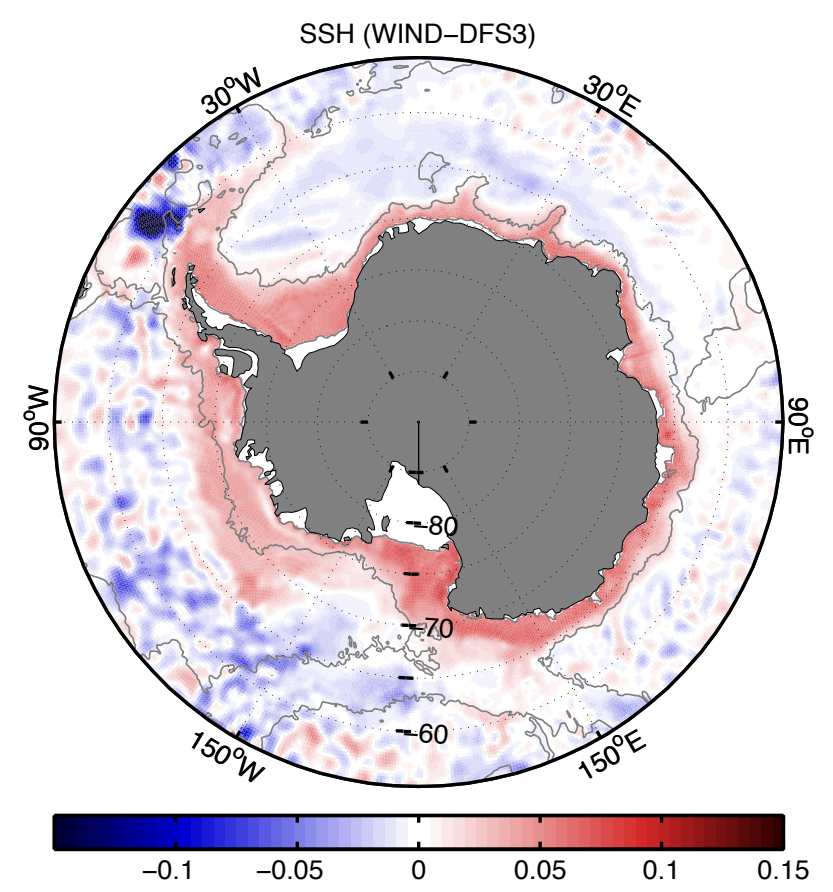

Fig. 14. SSH difference (in $\mathrm{m}$ ) between WIND and REF. A red area means a higher SSH in WIND. Grey line is the $3500 \mathrm{~m}$ bathymetry line.

Almost the same feature is observed between January and May (Fig. 15a). In January, SSH along the coast is lower than in May. In the open ocean, SSH is higher in January than in May. Consequently, the pressure gradient between the coast and the open ocean is lower during January, which inhibits the presence of a powerful ASC. As expected in SEASO (Fig. 15b), the SSH gradient difference between coastal area and open ocean between January and May is low compared to WIND + TEMP (Fig. 15a). To sum up, the effect of wind on the ASC seems to be due to a change in SSH gradient via a direct effect of Ekman drift, and this holds for the seasonal cycle of the amplitude of the ASC as well as for the annual mean of ASC transport.

\section{Conclusions}

The main goal of this study was to investigate the sensitivity of the ASC, defined for our purposes as the total westward flow between the Antarctic coast and the centers of the three Antarctic gyres, to different model characteristics such as the resolution and the atmospheric forcing, with a focus on the influence of the wind on the seasonal cycle of this current. The sensitivity experiments of the ASC to model resolutions were done in order to choose the model resolution best suited for the wind sensitivity experiments. 
a)

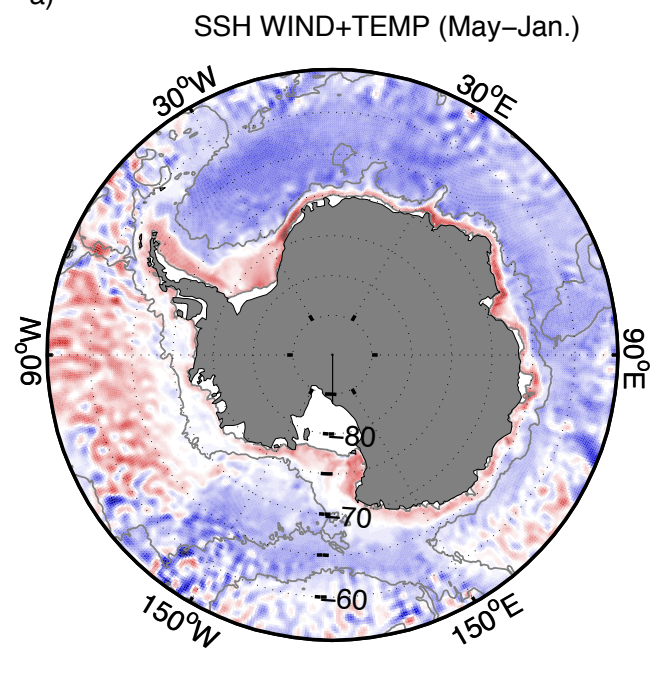

b)

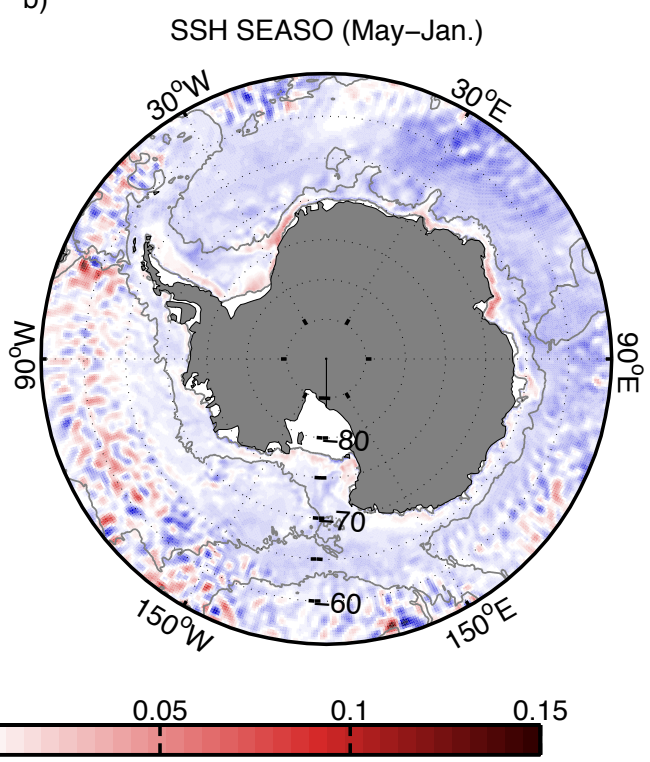

Fig. 15. SSH difference (in $\mathrm{m}$ ) between May and January in WIND + TEMP (a) and in SEASO simulations (b). A red area means a higher $\mathrm{SSH}$ in May. Grey line corresponds to the $3500 \mathrm{~m}$ bathymetry line.

A hierarchy of model global configurations $\left(2^{\circ}, 1^{\circ}, 0.5^{\circ}\right.$ and $0.25^{\circ}$ of resolution) was tested. All the simulations conducted in this study were run over the last 50 years with the same experimental design. To evaluate the realism of those simulations, general diagnostics devoted to Antarctic sea ice and to the transport through the Drake Passage and in the Weddell Gyre were computed. The modelled westward transport in coastal, shelf and slope regions was also thoroughly examined. The resolution does not seem to impact the sea ice extent, both in summer and winter. In summertime, the sea ice coverage computed by the model is largely underestimated in all cases. During winter, a slight overestimation of sea ice extent is simulated. Regarding the transport through the Drake Passage, all the simulations show a reasonable spread around the observations (from 117 to $147 \mathrm{~Sv}$ in the model, $136 \pm 8 \mathrm{~Sv}$ in the observations). In the southern branch of the Weddell Gyre, low-resolution models $\left(2^{\circ}\right.$ and $1^{\circ}$ resolutions) yield a mean transport of 24 and $33 \mathrm{~Sv}$, respectively, and the high-resolution models $\left(0.5^{\circ}\right.$ and $0.25^{\circ}$ resolution) simulate a mean transport of 63 to $70 \mathrm{~Sv}$, respectively, while observations give $56 \pm 8 \mathrm{~Sv}$. A detailed analysis of the model dynamics along East Antarctica revealed that the ASC transport at $2^{\circ}$ resolution is not continuous at Princess Elisabeth Trough (PET). At $1^{\circ}$ resolution, PET strongly impedes the ASC flow (only $1 \mathrm{~Sv}$ remains after the PET). At $0.25^{\circ}$ resolution, there is no recirculation along the Kerguelen Plateau due to a large Weddell Australian Antarctic Gyre in the model. This wide gyre is unrealistic, but the westward transport along the coastline is in agreement with observational estimates. At $0.5^{\circ}$ resolution, the ASC transport in the vicinity of the PET is realistic, and the small Prydz
Bay gyre is well reproduced. The half degree model provides results most consistent, with respect to gyres and coastal to slope flows, with the field observations. The quarter degree model, which intuitively might have provided better results, was hampered by it's treatment of steep and rugged bathymetry that typifies much of the region. Thus, the rest of our study was conducted with the southern regional configuration of the model based on the global configuration at $0.5^{\circ}$.

In order to indentify the role played by each forcing component in the ASC volume flux, five simulations were performed: four to test the effect of wind speed and air temperature and air humidity, and another one to test the effect of the seasonality of the wind. All simulations were carried out over the period 1980-1989. Two forcing fields were used. The first one is the Drakkar Forcing Set 3 (DFS3) in which turbulent variables (wind, temperature and humidity) are derived from ERA40 reanalysis. The second one (MAR) was built from results of the regional atmospheric model MAR applied over the Antarctic region. The MAR easterlies are $\pm 30 \%$ stronger than the DFS3 ones and they also have a larger seasonal cycle. Surface air temperatures are also lower in the MAR forcing compared to the DFS3 ones $\left(-4{ }^{\circ} \mathrm{C}\right.$ at $\left.66^{\circ} \mathrm{S}\right)$. The impacts of these differences in turbulent variables (radiation and precipitation are identical) on the model are diagnosed around Antarctica. Two changes are observed. The first one is the deepening of the ASC vein when the wind increases. With the MAR winds, the ASC reaches $1500 \mathrm{~m}$ instead of $700 \mathrm{~m}$ with the DFS3 winds. The other one is the increase in the total westward transport along the Antarctic coast when the wind increases $(+5 \mathrm{~Sv}$ when using MAR 
winds). A detailed comparison between the responses of the ASC to MAR and DFS3 winds indicates that the minimum and maximum of the seasonal cycle of the ASC transport in those two simulations occur in the same month in all sections considered in this study: this current is weak in January and strong in June. However, the amplitude of the seasonal cycle of ASC transport is different: $8 \mathrm{~Sv}$ along the east coast of Antarctica when using MAR wind and $6 \mathrm{~Sv}$ when using DFS3 wind. A final simulation without seasonal cycle of wind shows that more than $50 \%$ of the amplitude of the seasonal cycle of the ASC transport is due to the wind seasonal cycle. All the effect of the wind on the ASC seasonal cycle and ASC annual mean seems to be due to adjustment of sea surface height along Antarctica coasts. This is due to modification of the Ekman drift.

In conclusion of this study, we show that coarse resolution models (with typical resolution of climate model) are unable to simulate a realistic Antarctic Slope Current. Ocean-sea ice models needs at least a resolution of $25 \mathrm{~km}$ along the Antarctic continental slope to simulate it correctly. Secondly we show that the ASC is strongly sensitive to wind forcing and its seasonal variability is largely dominated by the wind seasonal variability.

Acknowledgements. The authors acknowledge support from the Fonds National de la Recherche Scientifique (F.R.S.-FNRSBelgium), the Belgian Federal Science Policy Office, Research Program on Science for a Sustainable Development, and the Fonds Special de la Recherche of the Université Catholique de Louvain, from the Ministère de l'Education Nationale et de la Recherche and from the Centre National de la Recherche Scientifique (CNRSFrance). Computations presented in this study were performed at Institut du Développement et des Ressources en Informatique Scientifique (IDRIS, Palaiseau, France) with the support of GENCI. Partial support from the European Commission under Contract SIP3-CT-2003-502885 (MERSEA project) is gratefully acknowledged. This work is a contribution of the DRAKKAR project. Support to DRAKKAR comes from various grants and programs listed hereafter: French national programs GMMC, LEFE, and PICS2475. The contribution of the Institut National des Sciences de l'Univers (INSU-France) to these programs is particularly acknowledged. DRAKKAR acknowledges the support from the Centre National d'Etudes Spatiales (CNES) through the OST/ST. H. Goosse is Research Associate with the F.R.S.-FNRS. The authors acknowledge the very constructive and precise comments of R. Muench and two anonymous reviewers.

Edited by: R. Muench

\section{References}

Aoki, S., Sasai, Y., Sasaki, H., Mitsudera, H., and Williams, G. D.: The cyclonic circulation in the Australian- Antarctic basin simulated by an eddy-resolving general circulation model, Ocean Dynam., 30(3), 743-757, doi:10.1007/s10236-009-0261-y, 2010.
Barnier, B., Madec, G., Penduff, T., Molines, J.-M., Treguier, A.M., Le Sommer, J., Beckmann, A., Biastoch, A., Böning, C., Dengg, J., Derval, C., Durand, E., Gulev, S., Remy, E., Talandier, C., Theeten, S., Maltrud, M., McClean, J., and De Cuevas, B.: Impact of partial steps and momentum advection schemes in a global ocean circulation model at eddy-permitting resolution, Ocean Dynam., 56, 543-567, 2006.

Beckmann, A. and Doesher, R.: A method for improved representation of dense water spreading over topography in geopotentialcoordinate models, J. Phys. Oceanogr., 27, 581-591, 1997.

Beardsley, R. C., Limeburner, R., and Owens, W. B.: Drifter measurements of surface currents near Marguerite Bay on the western Antarctic Peninsula shelf during austral summer and fall, 2001 and 2002, Deep-Sea Res. Pt. II, 51, 1947-1964, 2004.

Biastoch, A., Böning, C., Getzlaff, J., Molines, J.-M. and Madec, G.: Causes of interannual-decadal variability in the meridional overturning circulation of the mid-latitude North Atlantic Ocean, J. Clim. 21, 6599-6615, doi:10.1175/ 2008JCLI2404.1, 2008a.

Biastoch, A., Böning, C., Lutjeharms, J. R. E.: Agulhas leakage dynamics affects decadal variability in Atlantic overturning circulation, Nature, 456, 489-492, doi:10.1038/nature07426, 2008 b.

Bindoff, N. L., Rosenberg, M. A., and Warner, M. J.: On the circulation and water masses over the Antarctic continental slope and rise between 80 and 150E, Deep-Sea Res. Pt. II, 47, 2299-2326, 2000.

Brodeau, L., Barnier, B., Penduff, T., Treguier, A.-M., and Gulev, S.: An ERA40 based atmospheric forcing for global ocean circulation models, Ocean Model., 31, 88-104, 2010.

Brun, E., David, P., Sudul, M., and Brunot, G.: A numerical model to simulate snow cover stratigraphy for operational avalanche forecasting, J. Glaciol., 128, 13-22, 1992.

Cunningham, S., Alderson, S., King, B., and Brandon, M.: Transport and variability of the Antarctic circumpolar current in Drake Passage, J. Geophys. Res., 108, C05, doi:10.1029/2001JC001147, 2003.

Davis, A. M. J. and Mc Nider, R. T.: The Development of Antarctic Katabatic Winds and Implications for the Coastal Ocean, J. Atmos. Sci., 54, 1248-1261, 1997.

Deacon, G.: The hydrology of the Southern Ocean, Discovery Rep. 15, Institute of Oceanography Science, Southampton UK, 3-122, 1937.

DRAKKAR-Group: Eddy permiting ocean circulation hindcast of past decades, CLIVAR Exchanges Letters, 12, 8-10, 2007.

Fichefet, T. and Morales Maqueda, M. A.: Sensitivity of a global sea ice model to the treatment of ice thermodynamics and dynamics, J. Geophys. Res., 102, 12609-12646, doi:10.1029/97JC00480, 1997.

Fetterer, F. and Knowles, K.: Sea ice index monitors polar ice extent, Eos Trans., AGU, 16, 163, doi:10.1029/2004EO160007, 2004.

Gallee, H.: Simulation of the mesocyclonic Activity in the Ross Sea, Antarctica, Mon. Wea. Rev., 123, 2050-2069, 1995.

Gallée, H. and Schayes, G.: Development of a three dimensional meso-scale primitive equations model, katabatic winds simulation in the area of Terra Nova Bay, Ant. Mon. Wea. Rev. 122, 671-685, 1994.

Gallée, H., Guyomarc'h, G., and Brun, E.: Impact of snow drift on the antarctic ice sheet surface mass balance: Possible sensitivity to snow-surface properties, Bound.-Lay. Meteorol., 99, 1-19, 
2001.

Gallée H., Peyaud, V., and Goodwin I.: Simulation of the net snow accumulation along the Wilkes Land transect, Antarctica, with a regional climate model, Ann. Glaciol., 41, 1-6, 2005.

Gouretsky, V.: The large-scale thermohaline structure of the Ross Gyre, Oceanography of the Ross Sea, Antarctica, Berlin: Springer, 77-100, 1999.

Griffies, S. M., Böning, C., Bryan, F. O., Chassignet, E. P., Gerdes, R., Hasumi, H., Hirst, A., Treguier, A.-M., and Webb, D.: Developments in ocean climate modeling, Ocean Model., 2, 123-192, 2000.

Heywood, K. J. and Navaira Garabato, A. C.: On the fate of the Antarctic Slope Front and the origin of the weddell Front, J. Geophys. Res., 109, C06021, doi:10.1029/2003JC002053, 2004.

Heywood, K. J., Locarnini, R., Frew, R., Dennis, P., and King, B.: Transport and water masses of the Antarctic slope front system in the eastern Weddell Gyre. Ocean, Ice and Atmosphere: Interactions at the Antarctic Continental Margin, Antarctic Research Series, American Geophysical Union, Washington, 75, 203-214, 1998.

Heywood, K. J., Sparrow, M., Brown, J., and Dickson, R.: Frontal structures and antarctic bottom water flow through the Princess Elizabeth trough, Antarctica, Deep-Sea Res. Pt. I, 46, 7, 11811200, 1999.

Holland, P. R., Jenkins, A., and Holland, D. M.: Ice and ocean processes in the Bellingshausen Sea, Antarctica, J. Geophys. Res., 115, C05020, doi:10.1029/2008JC005219, 2010.

Jourdain, N. C. and Gallée, H.: Influence of the representation of glacier valleys across the Transantarctic Mountains in an atmospheric regional model, Clim. Dynam., 36(5-6), 1523 pp., doi:10.1007/s00382-010-0757-7, 2011.

Klatt, O., Fahrbach, E., Hoppema, M., and Rohardt, G.: The transport of the Weddell Gyre across the Prime Meridian, Deep-Sea Res. Pt. II, 52, 513-528, 2005.

Klatt, O., Boebel, O., and Farhbach, E.: A profiling Float's Sense of Ice, J. Atmos. Ocean. Tech., 24, 1301-1308, 2007.

Lachkar, Z., Orr, J. C., Dutay, J.-C., and Delecluse, P.: Effects of mesoscale eddies on global ocean distributions of CFC-11, $\mathrm{CO}_{2}$, and $\Delta^{14} \mathrm{C}$, Ocean Sci., 3, 461-482, doi:10.5194/os-3-461-2007, 2007.

Large, W. G. and Yeager, S. G.: Diurnal to decadal global forcing for ocean and sea-ice models: The data sets and flux climatologies, Technical Report TN-460+STR, NCAR, 105 pp., 2004.

Levitus, S., Boyer, T. P., Conkright, M. E., O’Brian, T., Antonov, J., Stephens, C., Stathopolos, L., Johnson, D., and Gelfeld, R.: World ocean database 1998, NOAA Atlas NESDID 18, US Government Printing Office, Washington, DC, 1998.

Madec, G.: the NEMO ocean engine, Note du Pôle de Modlisation de L'IPSL. Online access: http://www.nemo-ocean.eu/content/ download/15482/73217/file/NEMO_book_v3_3.pdf, 2008.

Madec, G. and Imbard, M.: A global ocean mesh to overcome the North Pole singularity, Clim. Dynam., 12, 381-388, 1996.

Martinson, D. G., Stammerjohn, S. E., Iannuzzi, R. A., Smith, R. C., and Vernet, R. C.: Western Antarctic Peninsula physical oceanography and spatio-temporal variability, Deep-Sea Res. Pt. II, 55, 1964-1987, 2008.

Mathiot, P.: Influence du forage atmosphérique sur la représentation de la glace de mer et des eaux de plateau en Antarctique dans une étude de modélisation numérique, Phd thesis, Université Joseph
Fourier, Online access: http://tel.archives-ouvertes.fr/docs/00/ 37/59/60/PDF/THESE.pdf, 2009.

Mathiot, P., Barnier, B., Gallée, G., Molines, J. M., Le Sommer, J., Juza, M., and Penduff, P.: Introducing katabatic winds in global ERA40 fields to simulate their impacts on the Southern Ocean and sea-ice, Ocean Model., 35, 3, 119-216, 2010.

McCartney, M. S. and Donohue, K. A.: A deep cyclonic gyre in the Australian-Antarctic Basin, Prog. Oceanogr., 75, 675-750, 2007.

Meijers, A. J. S., Klocker, A., Bindoff, N. L., Williams, G. D., and Marsland, S. J.: The circulation and water masses of the Antarctic shelf and continental slope between $30^{\circ} \mathrm{E}$ and $80^{\circ} \mathrm{E}$, DeepSea Res. Pt. II, 57, 723-737, 2010.

Murray, R. J.: Explicit generation of orthogonal grids for ocean models, J. Comput. Phys., 126, 251-273, 1996.

Nunes Vaz, R. A. and Lennon, G. W.: Physical oceanography of the Prydz Bay region of Antarctic waters, Deep-Sea Res. Pt. I, 43(5), 603-641, 1996.

Nunez-Riboni, I. and Fahrbach, E.: Seasonal variability of the Antarctic Coastal Current and its driving mechanisms in the Weddell Sea, Deep-Sea Res. Pt. I, 56, 1927-1941, 2009.

Orsi, A. H., Whitworth III, T., and Nowlin, W. D.:On the meridional extent and front of the Antarctic Circumpolar Current, Deep-Sea Res. Pt. I, 42(5), 641-673, 1995.

Park, Y.-H., Vivier, F., Roquet, F., and Kestenare, E.: Direct observations of the ACC transport across the Kerguelen Plateau, Geophys. Res. Lett., 36, L18603, doi:10.1029/2009GL039617, 2009.

Pauly, T., Nicol, S., Higginbottom, I., Hosie, G., and Kitchener, J.: Distribution and abundance of Antarctic krill (Euphausia superba) off East Antarctica (80-150 E) during the Austral summer of 1995/1996, Deep-Sea Res. Pt. II, 47, 2465-2488, 2000.

Penduff, T., Juza, M., Brodeau, L., Smith, G. C., Barnier, B., Molines, J.-M., Treguier, A.-M., and Madec, G.: Impact of global ocean model resolution on sea-level variability with emphasis on interannual time scales, Ocean Sci., 6, 269-284, doi:10.5194/os6-269-2010, 2010.

Petrelli, P., Bindoff, N. L., and Bergamasco, A.: The sea ice dynamics of Terra Nova Bay and Ross Ice Shelf Polynyas during a spring and winter simulation, J. Geophys. Res., 113, C09003, doi:10.1029/2006JC004048, 2008.

Pinones, A., Hofmann, E. E., Dinniman, M. S., Klinck, J. M.: Lagrangian simulation of transport pathways and residence times along the western Antarctic Peninsula, Deep-Sea Res. Pt. II, 58(13-16), 1524-1539, doi:10.1016/j.dsr2.2010.07.001, 2010.

Randall, D. A., Wood, R. A., Bony, S., Colman, R., Fichefet, T., Fyfe, J., Kattsov, V., Pitman, A., Shukla, J., Srinivasan, J., Stouffer, R. J., Sumi, A., and Taylor, K. E.: Cilmate Models and Their Evaluation, in: Climate Change: The Physical Science Basis. Contribution of Working Group I to the Fourth Assessment Report of the Intergovernmental Panel on Climate Change, edited by: Solomon, S., Qin, D., Manning, M., Chen, Z., Marquis, M., Averyt, K. B., Tignor, M., and Miller, H. L., Cambridge University Press, Cambridge, United Kingdom and New York, NY, USA, 2007.

Renner, A. H. H., Heywood, K. J., and Thorpe, S. E.: Validation of three global ocean models in the Weddell Sea, Ocean Model., 30, 1-15, 2009.

Rintoul, S. R.: Rapid freshening of Antarctica Bottom Water 
formed in the Indian and Pacific oceans, Geophys. Res. Lett., 34, L06606, doi:10.1029/2006GL028550, 2007.

Roquet, F.: La circulation océanique autour du plateau de Kerguelen: De l'observation à la modélisation. Phd thesis, Université Pierre et Marie Curie, Online access: http://tel.archives-ouvertes. fr/docs/00/43/14/83/PDF/these_roquet.pdf, 2009.

Simmons, A. J. and Gibson, J. K.: The era- 40 project plan. Technical report, ERA-40 project report series, 2000.

Smedsrud, L. H., Jenkins, A., Holland, D. M., and Nost, O. A.: Modeling ocean processes below Fimbulisen, Antarctica, J. Geophys. Res., 111, C01007, 1-14, doi:10.1029/2005JC002915, 2006.

Steele, M., Morley, R., and Ermold, W.: PHC: a global ocean hydrography with a high quality Arctic Ocean, J. Clim., 14, 2079 2087, 2001.

Sverdrup, H. U.: The currents off the coast of Queen Maud Land, Nor. Geogr. Tidsskr., 14, 239-249, 1953.
Treguier, A.-M., Barnier, B., de Miranda, A., Molines, J.-M., Grima, N., Imbard, M., Madec, G., Messager, C., and Michel, S.: An eddy permitting model of the Atlantic circulation: evaluating open boundary conditions, J. Geophys. Res., 106(10), 2211522129, doi:106:22115-11129, 2001.

Treguier, A.-M., England, M. H., Rintoul, S. R., Madec, G., Le Sommer, J., and Molines, J.-M.: Southern Ocean overturning across streamlines in an eddying simulation of the Antarctic Circumpolar Current, Ocean Sci., 3, 491-507, doi:10.5194/os-3491-2007, 2007.

Von Gyldenfeldt, A.-B., Fahrbach, E., Garcia, M. A., and Schroder, M.: Flow variability at the tip of the Antarctic Peninsula, DeepSea Res. Pt. II, 49, 4743-4766, 2002.

Whitworth III, T., Orsi, A. H., Kim, S. J., Nowlin, W. D., and Locarmini, R. A.: Ocean, Ice, and Atmosphere: Interac- tions at the Antarctic Continental Margin, in: Antarctic Research Series, edited by: Jacobs, S. S. and Weiss, R. F., 75, Amer. Geophys. Union, 1-28, 1998. 